\title{
Cereal bar enriched with cowpea bean whole flour, cashew nut, and raisin banana ${ }^{1}$
}

\author{
Barra de cereal adicionada de farinha integral de feijão-caupi, castanha de caju e \\ banana passa
}

\author{
Regilda Saraiva dos Reis Moreira-Araújo ${ }^{2 *}$, Iuska Grazielle Macêdo de Sousa ${ }^{2}$, Rodrigo Barbosa Monteiro \\ Cavalcante $^{3}$, Marcelo Antônio Morgano ${ }^{4}$ and Marcos Antônio da Mota Araújo ${ }^{5}$
}

\begin{abstract}
The objective of this study is to develop a cereal bar enriched with cowpea bean whole flour, cashew nut, and raisin banana and evaluate its acceptance and chemical composition. Three formulations with varying concentrations of cowpea were developed: B1 with 5.25\%, B2 with 7.5\%, and B3 with 15\% flour. Ten trained tasters evaluated the bar's sensory attributes using the hedonic scale. After this test, 100 untrained tasters analyzed two formulations using multiple and pairwise comparisons, and purchase intention tests. Moisture was determined by oven drying and ash content was determined after calcination of samples in a muffle furnace. Protein content was obtained by the Macro-Kjeldahl method and lipids were isolated using the Soxhlet extraction method. Carbohydrates were determined by difference and minerals by atomic emission spectrometry with an inductively coupled plasma source. The trained team scored bar B3 with the lowest average for flavor. The non-trained tasters' test showed that bars B1 and B2 are commercially viable and presented no difference in the pairwise comparison. The ash, lipid, and protein content increased on using a higher concentration of cowpea. Bar B2 presented a higher content of ashes, lipids, proteins, and the lowest amount of carbohydrates and humidity. The bars were identified as a source of iron, phosphorus, magnesium, and zinc, with high content of copper and manganese. Thus, the cereal bar has a high nutrient content and sensory viability.
\end{abstract}

Key words: Vigna unguiculata (L.) Walp. Sensory analysis. Physical-chemical composition.

RESUMO - Este trabalho objetivou elaborar barra de cereal adicionada de farinha integral de feijão-caupi, castanha de caju e banana passa e avaliar sua aceitação e composição química. Foram desenvolvidas três formulações, B1 com 5,25\% de feijãocaupi, B2 7,5\% e B3 com 15\%. Os atributos sensoriais foram avaliados por 10 provadores treinados utilizando escala hedônica. Após este teste, duas formulações foram analisadas por 100 provadores não treinados utilizando os testes de comparação múltipla, comparação pareada e intenção de compra. A umidade foi determinada por secagem em estufa e as cinzas após calcinação das amostras em forno mufla. O teor de proteínas foi obtido pelo método de Macro-Kjeldahl e o de lipídeos por extração a quente em aparelho de Soxhlet. Os carboidratos foram determinados por diferença e os minerais pela técnica de espectrometria de emissão atômica com fonte de plasma indutivamente acoplado. Após teste com a equipe treinada, observou-se que a barra B3 recebeu a menor média em relação ao sabor. Com os provadores não treinados, verificou-se que as barras B1 e B2 são viáveis comercialmente e não apresentaram diferença na comparação pareada. O aumento de feijão-caupi promoveu um incremento nos teores de cinzas, lipídeos e proteínas. A barra B2 apresentou maior teor de cinzas, lipídeos e proteínas e a menor quantidade de carboidratos e umidade. As barras se apresentaram como fontes de ferro, fósforo, magnésio e zinco e com alto conteúdo de cobre e manganês. Concluiu-se que a barra de cereal elaborada contém alto teor de nutrientes e apresenta viabilidade sensorial.

Palavras-chave: Vigna unguiculata (L.) Walp. Análise sensorial. Composição físico-química.

DOI: 10.5935/1806-6690.20210026

Editor-in-Article: Prof. Alek Sandro Dutra - alekdutra@ufc.br

*Author for correspondence

Received for publication 19/02/2020; approved on 18/01/2021

${ }^{1}$ Pesquisa financiada pelo CNPq via Editais Universais 14/2011 e 01/2016

${ }^{2}$ Departamento de Nutrição, Universidade Federal do Piauí/UFPI, Teresina-PI, Brasil, regilda@ufpi.edu.br (orcid ID 0000-0002-3669-2358), iuskagrazielle@hotmail.com (ORCID ID 0000-0003-1009-0313)

${ }^{3}$ Programa de Pós-Graduação em Alimentos e Nutrição/PPGAN, Universidade Federal do Piauí/UFPI, Teresina- PI, Brasil, rbmc89@hotmail.com (ORCID ID 0000-0003-2649-6588)

${ }^{4}$ Centro de Ciência e Qualidade de Alimentos/CCQA, Instituto de Tecnologia de Alimentos/ITAL, Campinas-SP, Brasil, morgano@ital.sp.gov.br (ORCID ID 0000-0001-8332-3953)

${ }^{5}$ Gerência de Planejamento, Fundação Municipal de Saúde (FMS), Teresina, Piauí, Brasil, regmarjoao@hotmail.com (ORCID ID 0000-0002-9061-7359) 


\section{INTRODUCTION}

The demand and consumption of healthy and practical foods has strengthened the cereal bar market. Cereal bars are a feasible option for supplemental nutrition as they are a good source of carbohydrates, protein, and dietary fiber. Besides being easy to buy and transport, they also provide a quick energy boost. Although cereal bars are marketed in different types, brands, flavors, toppings, shapes, and textures, there is a constant search for new ingredients and formulations (SOUSA et al., 2016).

Owing to its high nutritive value and widespread cultivation, the use of cowpea flour in the preparation of cereal bars is a viable option. Cowpea bean is widely distributed both nationally and internationally. Niger, Nigeria, and Brazil have the largest cultivated area and the highest production of cowpea. The largest producers in Brazil are the states of Mato Grosso, Ceará, Piauí, Pernambuco, Bahia, and Paraíba (FALADE; KOLAWOLE, 2013; FREIRE-FILHO et al., 2011; MARQUES et al., 2015).

Cereal bars are made from a mixture of cereals having a pleasant taste. The presence of fruits, oilseeds, nuts, and seeds in the formulation contributes to the nutritional value of these products (SILVA et al., 2011). Addition of cowpea increases the amount of carbohydrates, protein, dietary fiber, and micronutrients, such as minerals including potassium, phosphorus, iron, calcium, manganese, magnesium, and zinc, and vitamins including thiamine, riboflavin, pyridoxine, folacin, and niacin. Cowpea also contains bioactive compounds, such as phenolics and polyamines (BARROS et al., 2017; CAVALCANTE et al., 2019; MOREIRA-ARAÚJO et al., 2017).

Food enrichment and development are important not only for the food industry, but also for the improvement of the diet and nutrition of the population, because creating new products or enriching the existing ones improves their nutritional value and helps to control nutritional deficiencies. This strategy is pertinent in developing countries (CAVALCANTE et al., 2016; FROTA et al., 2010).

Considering the points stated above, the objective of the present study is to prepare a cereal bar with cowpea bean whole flour, cashew nut, and raisin banana and evaluate its acceptance and chemical composition.

\section{MATERIAL AND METHODS}

\section{Raw materials}

The cowpea beans of cultivar BR17 Gurguéia were sourced from the experimental field of EMBRAPA MeioNorte in Teresina, PI, Brazil located at an altitude of 72 meters, $5^{\circ} 5^{\prime} \mathrm{S}$ and $42^{\circ} 48^{\prime} \mathrm{W}$. The other raw materials (oat flakes, rice flakes, cornstarch biscuit, cashew nuts, raisin banana, glucose syrup, brown sugar, and bee honey) used in the preparation of the product were procured from local retailers in Teresina, PI, Brazil.

\section{Processing of the cowpea whole flour}

Based on Frota et al. (2010), the cowpea grains were dried $\left(70{ }^{\circ} \mathrm{C} / 6 \mathrm{~h}\right)$ in a ventilated oven (Quimis, model 314D242, Diadema, Brazil) and then ground in a semi-industrial mill (Fritsch) to obtain the cowpea whole flour (CWF). The flour was used immediately after its production.

\section{Preparation of cereal bars}

After the sensory pre-tests, the dry ingredients and the binding syrup were used in a 50:50 proportion to optimize the development of the cereal bars. Three formulations were developed where CWF partially (B1 and B2) and totally (B3) substituted the cornstarch biscuit. The percentage of CWF used in the formulations were $0 \%$ (control - BC), 5.25\% (B1), 7.5\% (B2), and 15\% (B3) (Table 1).

To prepare the bars, cornstarch biscuits were processed in a blender and sieved to obtain the flour. Cashew nuts were ground in an iron pestle, and the raisin banana was cut into small cubes with a stainlesssteel knife.

According to the methodology adapted from Gomes et al. (2010), the ingredients were divided into dry (CWF, cornstarch biscuit flour, oat flakes, rice flakes, cashew nuts, and raisin banana) and wet portions (brown sugar, bee honey and glucose syrup) to produce the cereal bars.

Table 1 - Percentage of raw materials used in the preparation of cereal bars

\begin{tabular}{lcccc}
\hline \multirow{2}{*}{ Raw materials } & \multicolumn{5}{c}{ Formulations (\%) } \\
\cline { 2 - 5 } & BC & B1 & B2 & B3 \\
\hline Binding Syrup & & & & \\
\hline Brown sugar & 10 & 10 & 10 & 10 \\
Bee honey & 25 & 25 & 25 & 25 \\
Glucose syrup & 15 & 15 & 15 & 15 \\
\hline Dry & & & & \\
\hline Cowpea whole flour (CWF) & - & 5.25 & 7.5 & 15 \\
Cornstarch biscuit flour & 15 & 9.75 & 7.5 & - \\
Oat flakes & 12 & 12 & 12 & 12 \\
Rice flakes & 6 & 6 & 6 & 6 \\
Cashew nuts & 9 & 9 & 9 & 9 \\
Raisin banana & 8 & 8 & 8 & 8 \\
\hline
\end{tabular}


The dry ingredients were mixed in a stainless-steel rectangle shaped baking pan and placed in a ventilated oven $\left(100{ }^{\circ} \mathrm{C} / 15 \mathrm{~min}\right)$. The binding syrup ingredients were mixed and placed in a water bath $\left(100{ }^{\circ} \mathrm{C} / 2 \mathrm{~min}\right)$. After 15 minutes, the dry ingredients were added to the binding syrup, forming a mass, which was pressed and shaped with a spatula in a stainless-steel rectangle shaped baking pan covered with baking paper, where it was left to cool down to room temperature.

After cutting into a standard shape, the bars were packed in aluminum foil and stored at room temperature for further analysis.

\section{Sensory analysis}

Initially, the formulations B1, B2 and B3 were evaluated by a group of ten trained tasters using the 9-point structured hedonic scale test, ranging from (1) "Dislike Extremely" to (9) "Like Extremely". In this analysis, the attributes of appearance, color, aroma, taste, texture, and overall impression were evaluated.

Subsequently, the formulations with the best results proceeded to sensory testing with 100 untrained tasters of both sexes, aged between 18 to 50 years.

The untrained tasters performed three sensory tests. For the multiple comparison test, a structured 9-point scale was used, ranging from (1) "extremely better than the standard" to (9) "extremely worse than the standard". The pairwise comparison and purchase intention tests were performed only with the formulations enriched with CWF. A 5-point structured scale ranging from (1) "definitely would not buy" to (5) "definitely would buy" was used (DUTCOSKY, 2013).

Samples were served in $50 \mathrm{~mL}$ plastic cups with a three-digit code obtained from a table of random numbers. They were tested monadically using the complete block design with three repetitions. The tests were performed between 2 and 5 pm.

\section{Centesimal composition}

Moisture content was determined after oven drying (Quimis, model 314D242, Diadema, Brazil) at $105{ }^{\circ} \mathrm{C}$ and ash content was determined after calcination of the samples in a muffle furnace (Quimis, model Q-318M21, Diadema, Brazil) at $550{ }^{\circ} \mathrm{C}$. The protein content was determined by the Macro-Kjeldahl method with a conversion factor of 6.25 , and the lipid content was determined by hot extraction using petroleum ether as a solvent in a Soxhlet apparatus (Tecnal, TE-044, Piracicaba, Brazil) (ASSOCIATION OF OFFICIAL ANALYTICAL CHEMISTRY, 2005). The total carbohydrate was calculated by difference.

\section{Minerals}

Calcium, copper, iron, phosphorus, sodium, magnesium, manganese, and zinc were determined using atomic emission spectrometry with an inductively coupled plasma source technique, after calcination of the samples in a muffle furnace at $450{ }^{\circ} \mathrm{C}$ (HORWITZ; LATIMER JUNIOR, 2000). This analysis was performed at the Center for Food Science and Quality of the Institute of Food Technology (ITAL) in Campinas, SP, Brazil.

\section{Ethical aspects}

This study was submitted to the Research Ethics Committee of the Federal University of Piauí (UFPI) and was approved in its ethical and methodological aspects (CAAE: 0179.0.045.000-11). Before the test, the tasters who participated in the sensory team read and signed the Informed Consent Form (ICF), according to the guidelines and standards for research on human beings (BRAZIL, 2013).

\section{Statistical analysis}

The collected data were analyzed using the EPI Info 6.04b software (DEAN et al., 1994). The test of $\chi^{2}$ was used to analyze the data in the pairwise comparison test. The Student's $t$-test was used for comparison of means between two variables, and Tukey's test was used for multiple comparisons at 5\% level.

\section{RESULT AND DISCUSSION}

\section{Sensory analysis}

Table 2 shows the mean scores assigned to the cereal bars by the trained tasters (B1, B2 and B3).

The sensory attributes of the three formulations were evaluated and assigned mean scores ranging from 7 ("Like Moderately") to 9 ("Like Extremely"). This result demonstrates the suitability of the developed formulations once they presented sensorially acceptable attributes. The bars showed statistically significant difference only in relation to the flavor attribute. This difference can be explained by the total substitution of the cornstarch biscuit flour by the CWF, causing an aftertaste in bar B3. Thus, formulations B1 and B2 were selected for sensory tests with untrained tasters.

Table 3 shows the results of the multiple comparison test.

Tasters evaluated the formulations ranging from "regularly better than the standard" to "no difference from the standard", according to the multiple comparison scale. This test ratifies the feasibility of adding cowpea to cereal bar formulations, since the developed products are commercially competitive. Considering the frequency of the attributed scores, $73 \%$ and $69 \%$ of the tasters considered bars B1 and B2 better than the standard bar, respectively (Figure 1). 
Table 2 - Mean and standard deviation of the sensory attribute scores of cereal bars with CWF evaluated by trained tasters

\begin{tabular}{lcccccc}
\hline Formulations & Appearance & Color & Aroma & Taste & Texture & Overall impression \\
\hline B1 & $8.2 \pm 1.23 \mathrm{a}$ & $8.4 \pm 1.01 \mathrm{a}$ & $7.2 \pm 0.98 \mathrm{a}$ & $8.1 \pm 1.09 \mathrm{a}$ & $7.8 \pm 1.01 \mathrm{a}$ & $7.9 \pm 1.01 \mathrm{a}$ \\
B2 & $8.5 \pm 1.02 \mathrm{a}$ & $8.4 \pm 1.11 \mathrm{a}$ & $7.6 \pm 1.00 \mathrm{a}$ & $8.3 \pm 1.05 \mathrm{a}$ & $8.0 \pm 1.04 \mathrm{a}$ & $8.3 \pm 1.01 \mathrm{a}$ \\
B3 & $7.9 \pm 1.01 \mathrm{a}$ & $8.3 \pm 1.34 \mathrm{a}$ & $7.1 \pm 1.03 \mathrm{a}$ & $7.1 \pm 1.00 \mathrm{~b}$ & $7.6 \pm 1.03 \mathrm{a}$ & $7.3 \pm 1.00 \mathrm{a}$ \\
\hline
\end{tabular}

Equal superscript letters between formulations do not represent statistically significant difference between means, Tukey test at $5 \%$ level ( $>0.05$ ), $95 \%$ CI

Table 3 - Mean and standard deviation of the scores of bars B1 and B2 compared to the standard sample

\begin{tabular}{lc}
\hline Formulations & Mean + Standard Deviation \\
\hline B1 & $3.9+0.01 \mathrm{a}$ \\
B2 & $4.6+0.01 \mathrm{a}$ \\
\hline
\end{tabular}

Equal letters do not represent statistically significant difference between means, Student's $t$-test at $5 \%$ level (p>0.05), $95 \%$ CI

Figure 1 - Percentage of scores assigned to cereal bars made using CWF in the multiple comparison test

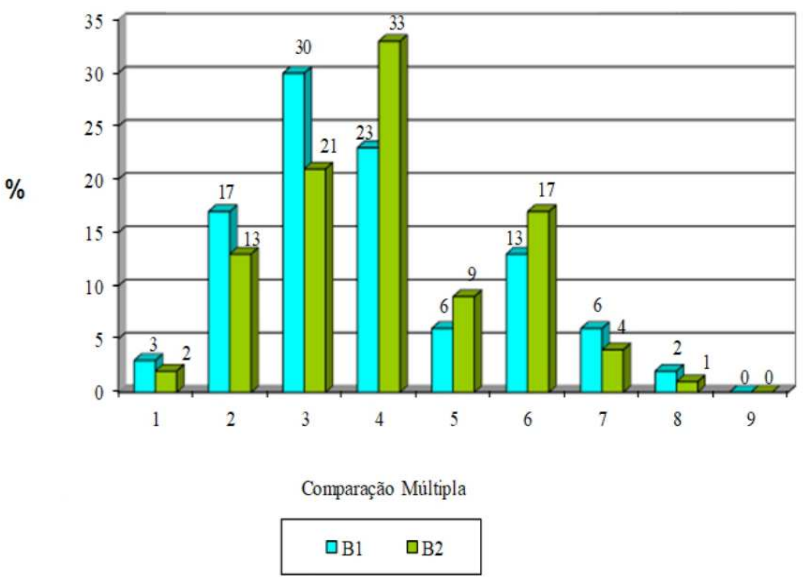

Embedded text: Multiple Comparison

The pairwise comparison test, applied to the panel of untrained tasters, also showed no statistically significant difference in product preference between B1 and B2 formulations (Table 4).

As for the purchase intention test, formulations B1 and B2 showed a positive intent of $71 \%$ and $69 \%$, respectively, which indicated that consumers would have a high intent to purchase these products (Figure 2). This result was higher than that observed in cheese bread with cowpea bean developed by Cavalcante et al. (2016). In the mentioned study, the favorable purchase intentions of cheese bread with $8 \%$ CWF were $50 \%$. On the other hand, Abreu et al. (2020) obtained $88 \%$ of positive purchase intentions for nuggets formulated with acerola fruit residue and cowpea.
Just like the other tests performed, this test confirms the acceptance of the products and the sensory similarity between the two developed formulations.

\section{Centesimal composition}

Table 5 shows the results of the analyses of centesimal composition in formulations BC, B1, and B2.

According to Lima et al. (2010) cereals have total ash content between 0.3 and $3.3 \%$, and the cereal bars of this study exhibited the expected ash content. Frota et al. (2010), recorded ash contents of 3.96 and $3.72 \%$, when preparing biscuits and swiss rolls with cowpea bean, respectively. However, these products contained $20 \%$ of CWF in their formulations and showed a reduction in the sensory acceptance mean. Thus, not only the nutritional value, but also sensory and technical characteristics of products that can be enriched with other flours instead of wheat flour, should be analyzed.

The moisture content of the formulated products remained below $15 \%$, which is the limit established by Resolution CNNPA No. 12 of 1978 for products based on cereals and derivatives. According to Costa et al. (2005), this result can contribute positively to the quality and stability of the formulated products. In contrast, Sousa et al. (2016) developed umbu flavored diet cereal bars, with a mean moisture value of $40.88 \%$.

Lipid content in the cereal bars ranged between 7.66 to $8.66 \%$ (Table 5). Despite the increase in lipid content in formulations that have a higher concentration of CWF, Cavalcante et al. (2017) reported that cowpea has a significant amount of unsaturated fatty acids (45.6 - 78.1\%). Freitas and Moretti (2006) determined 4 to $12 \%$ of lipids in conventional cereal bar samples. 
Table 4 - Results of pairwise comparison test between cereal bars B1 and B2

\begin{tabular}{lccc}
\hline Formulations & Number of tasters & $\%$ & Statistic \\
\hline B1 & 51 & 51.0 & $\chi^{2}=0.08$ \\
B2 & 49 & 49.0 & $\mathrm{P}=0.778$ \\
\hline TOTAL & 100 & 100 & \\
\hline
\end{tabular}

Figure 2 - Percentage of purchase intention of cereal bars B1 and B2

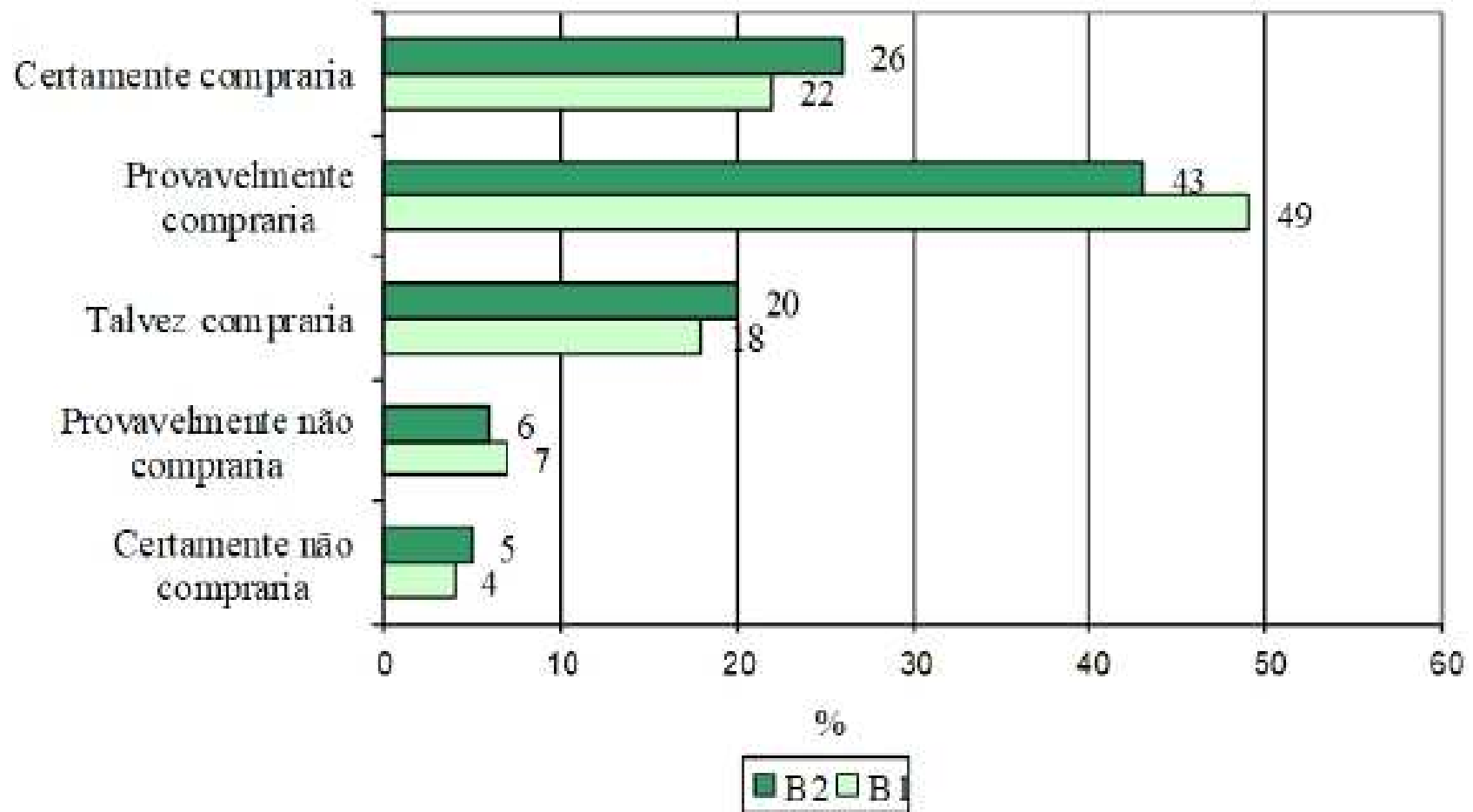

Embedded text: Definitely would buy / Probably would buy / Might buy / Probably would not buy / Definitely would not buy

Table 5 - Centesimal composition of BC, B1, and B2 formulations of cereal bars enriched with cowpea whole flour, cashew nut, and raisin banana

\begin{tabular}{|c|c|c|c|c|c|c|}
\hline & \multicolumn{3}{|c|}{ Formulations } & \multicolumn{3}{|c|}{ RDI for adults $\%$ of adequacy* } \\
\hline & $\mathrm{BC}$ & $\mathrm{B} 1$ & B2 & $\mathrm{BC}$ & B1 & $\mathrm{B} 2$ \\
\hline Ashes & $1.19 \pm 0.01 \mathrm{a}$ & $1.23 \pm 0.01 \mathrm{a}$ & $1.43 \pm 0.03 b$ & - & - & - \\
\hline Moisture & $11.55 \pm 0.98 \mathrm{a}$ & $11.22 \pm 0.45 \mathrm{a}$ & $10.88 \pm 0.56 \mathrm{~b}$ & - & - & - \\
\hline Lipids & $7.66 \pm 0.11 \mathrm{a}$ & $8.16 \pm 0.32 b$ & $8.66 \pm 0.76 \mathrm{c}$ & 25.53 & 27.20 & 28.86 \\
\hline Proteins & $5.67 \pm 0.21 \mathrm{a}$ & $6.75 \pm 0.13 b$ & $9.50 \pm 0.16 \mathrm{c}$ & 11.34 & 13.50 & 19.00 \\
\hline carbohydrates Total & $73.94 \pm 5.56 \mathrm{a}$ & $72.64 \pm 4.8 \mathrm{a}$ & $69.53 \pm 2.75 b$ & 56.88 & 55.88 & 53.48 \\
\hline
\end{tabular}

Equal horizontal letters do not present statistically significant difference between means, Tukey test at $5 \%$ level ( $>0.05)$, 95\% CI, *Percentage of coverage calculated from the values of recommended daily intake (RDI) of macronutrients for adults (BRAZIL, 2005)

The protein content of the bars showed a statistically significant increase according to the percentage of CWF used in the formulation. Cowpea also improved the protein content in products prepared by Cavalcante et al. (2016); Frota et al. (2010) and Landim et al. (2016). According to Brazil (2012), formulations B1 and B2 are sources of protein. On the other hand, Márquez-Villacorta and Pretell-Vásquez (2018) had developed cereal bars with oat bran, pineapple peel, and quinoa and obtained products with high protein content $(>12 \mathrm{~g} / 100 \mathrm{~g})$. 
Table 6 - Mineral content of BC, B1, and B2 formulations of cereal bars enriched with cowpea whole flour, cashew nut, and raisin banana

\begin{tabular}{|c|c|c|c|c|c|c|c|}
\hline \multirow{2}{*}{ Minerals (mg/100 g) } & \multicolumn{3}{|c|}{ Formulations } & \multirow{2}{*}{ Value* (mg) } & \multicolumn{3}{|c|}{ RDI for adults $\%$ of adequacy } \\
\hline & $\mathrm{BC}$ & B1 & $\mathrm{B} 2$ & & $\mathrm{BC}$ & $\mathrm{B} 1$ & $\mathrm{~B} 2$ \\
\hline Calcium & $39 \pm 1 \mathrm{a}$ & $42 \pm 2 \mathrm{a}$ & $43 \pm 1 \mathrm{a}$ & 1000 & 3.9 & 4.2 & 4.3 \\
\hline Copper & $0.30 \pm 0.03 \mathrm{a}$ & $0.33 \pm 0.03 \mathrm{a}$ & $0.40 \pm 0.02 \mathrm{~b}$ & 0.9 & 33.3 & 36.7 & 44.4 \\
\hline Iron & $2.16 \pm 0.07 \mathrm{a}$ & $2.43 \pm 0.22 \mathrm{a}$ & $3.00 \pm 0.16 \mathrm{a}$ & 14 & 15.4 & 17.4 & 21.4 \\
\hline Phosphorus & $137 \pm 6 \mathrm{a}$ & $149 \pm 11 b$ & $169 \pm 6 c$ & 700 & 20 & 21.3 & 24 \\
\hline Sodium & $120 \pm 5 \mathrm{a}$ & $93 \pm 1 b$ & $78 \pm 3 c$ & 2400 & 5 & 3.9 & 3.2 \\
\hline Magnesium & $60 \pm 3 \mathrm{a}$ & $64.1 \pm 0.3 \mathrm{a}$ & $71 \pm 1 \mathrm{~b}$ & 260 & 23 & 24.7 & 27.3 \\
\hline Manganese & $1.26 \pm 0.09 \mathrm{a}$ & $1.20 \pm 0.09 \mathrm{a}$ & $1.31 \pm 0.04 \mathrm{a}$ & 2.3 & 54.8 & 52.2 & 57 \\
\hline Zinc & $1.43 \pm 0.05 \mathrm{a}$ & $1.69 \pm 0.15 b$ & $1.89 \pm 0.15 \mathrm{c}$ & 7 & 20.4 & 24 & 27 \\
\hline
\end{tabular}

Equal horizontal letters do not present statistically significant difference between means, Tukey test at $5 \%$ level (p>0.05), 95\% CI, *(BRAZIL, 2005)

Formulation B2 presented the lowest content $(69.53 \%)$ of total carbohydrates (Table 5). This result may be due to the replacement of the cornstarch biscuit flour by CWF.

Table 5 shows that the bars provide more than $50 \%$ of the RDI of carbohydrates for adults (BRAZIL, 2005).

\section{Minerals}

Table 6 shows the mineral contents determined in the $\mathrm{BC}, \mathrm{B} 1$, and $\mathrm{B} 2$ cereal bars.

The B2 formulation (7.5\% CWF) presented the highest content of copper, phosphorus, magnesium, and zinc $(\mathrm{p} \leq 0.05)$. This formulation also showed a reduction in sodium content that confirms the nutritional quality of the product, since the traditional / commercial formulations of cereal bars tend to have significant content of this mineral. Cavalcante et al. (2016) corroborate this result.

The cereal bars in the present study had lower iron content as compared to the cereal bar developed by Freitas and Moretti (2006). This study obtained $5.1 \mathrm{mg} / 100 \mathrm{~g}$ of iron (36.46\% of RDI/adults) in a cereal bar prepared from texturized soy protein, wheat germ, oatmeal, and raisin banana. When compared to products with added cowpea, the B1 and B2 bars showed higher iron content than the biscuit $(1.56 \mathrm{mg} / 100 \mathrm{~g})$, the swiss roll $(1.16 \mathrm{mg} / 100 \mathrm{~g})$ and the cheese bread $(0.8 \mathrm{mg} / 100 \mathrm{~g})$ developed by Frota et al. (2010) and Cavalcante et al. (2019), respectively.

According to Brazil (2012), considering the RDI for adults, cereal bars are good sources of iron, phosphorus, magnesium, and zinc with high content of copper and manganese. The B2 formulation has low sodium content.

\section{CONCLUSION}

The sensory analysis of the developed formulations showed the tasters' acceptance and purchase intention because of the sensory attributes of the product. The addition of cowpea in the formulations increased the ash, lipid, and protein content levels. The bars are a source of iron, phosphorus, magnesium, and zinc and a high content of copper and manganese. The results of this study show that producing cereal bars with regional, easy to access raw materials is viable, and that these materials can be used to produce bars with a high nutrient content and sensory viability.

\section{ACKNOWLEDGMENTS}

The author thanks the National Council for Scientific and Technological Development (CNPq) for the scientific-technological initiation scholarship (PIBIT-CNPq) granted, for the funding via Edital Universal 14/2011, Process 482292/2011-3 and Edital Universal 01/2016, Process 431314/2016-0 and to EMBRAPA Meio-Norte for providing the cowpea beans.

\section{REFERENCES}

ABREU, B. B. et al. Development of a nugget based on the acerola residue (Malpighia emarginata D. C) and cowpea (Vigna unguiculata L.). Brazilian Journal of Development, v. 6, n. 2, p. 9446-9453, 2020.

ASSOCIATION OF OFFICIAL ANALYTICAL CHEMISTRY. Official methods of analysis of the AOAC International. 16. ed. Arlington: AOAC, 2005. 1025 p. 
BARROS, N. V. A. et al. Effect of cooking on the bioactive compounds and antioxidant activity in grains cowpea cultivars. Revista Ciência Agronômica, v. 28, n. 5, p. 824-831, 2017.

BRAZIL. Ministry of Health. Resolution $n^{\circ}$. 54, of November 12, 2012. Provides for technical regulations on supplementary nutritional information. Diário Oficial da República Federativa do Brasil, Brasilia, DF, 19 out. 2012.

BRAZIL. Ministry of Healt. Resolution $n^{\circ} .269$, of September 22, 2005. Technical regulation on recommended daily intake (RDI) of protein, vitamins and minerals. Diário Oficial da República Federativa do Brasil, Brasilia, DF, 23 set. 2005.

BRAZIL. Ministry of Healt. Resolution $n^{\circ}$. 466, of December 12, 2012. Provides for guidelines and regulatory standards for research involving human beings. Diário Oficial da República Federativa do Brasil, Brasilia, DF, 13 jun. 2013.

CAVALCANTE, R. B. M. et al. Cheese bread enriched with biofortified cowpea flour. Revista Ciência e Agrotecnologia, v. 40, n. 1, p. $97-103,2016$.

CAVALCANTE, R. B. M. et al. Effect of thermal processing on chemical compositions, bioactive compounds, and antioxidant activities of cowpea cultivars. Revista Caatinga, v. 30, n. 4, p. 1050-1058, 2017.

CAVALCANTE, R. B. M. et al. Mineral content, phenolic compounds and bioactive amines of cheese bread enriched with cowpea. Food Science and Technology, v. 39, n. 4, p. 843-849, 2019.

COSTA, L. A. et al. Development of bar food based on residue from the manufacture of cassava flour. Alimentos e Nutrição, v. 16, n. 4, p. 389-396, 2005.

DEAN, A. G. et al. Epi Info, version 6: a Word processing, database, and statistics program for epidemiology on microcomputers. Atlanta, Georgia: Centers for Disease Control and Prevention, 1994.

DUTCOSKY, S. D. Sensory analysis of food. 4. ed. Curitiba: Champagnat, 2013. $531 \mathrm{p}$.

FALADE, K. O.; KOLAWOLE, T. A. Effect of irradiation dose on physical, functional and pasting properties of cowpea (Vigna unguiculata L. Walp) cultivars. Journal of Food Process Engineering, v. 36, n. 2, p. 147-59, 2013.
FREITAS, D. G. C.; MORETTI, R. H. Characterization and sensorial evaluation of functional cereal bar. Ciência e Tecnologia de Alimentos, v. 26, n. 2, p. 318-324, 2006.

FREIRE FILHO, F. R. et al. Cowpea in Brazil: production, genetic improvement, advances and challenges. Teresina: Embrapa Meio-Norte, 2011. 81 p.

FROTA, K. M. G. et al. Utilization of cowpea flour in the development of bakery products. Ciência e Tecnologia de Alimentos, v. 30, n. 1, p. 44-50, 2010.

GOMES, F. O. et al. Development of cereal bars of flour albedo of passion (Passiflora edulis). Revista ACTA Tecnológica, v. 5, n. 2, p. 115-125, 2010.

HORWITZ, W.; LATIMER JUNIOR, G. W. Official methods of analysis of the Association of Official Analytical Chemists. 17. ed. Gaithersburg, Maryland: AOAC, 2000.

LANDIM, L. A. S. R. et al. Impact of the two different iron fortified cookies on treatment of anemia in preschool children in Brazil. Nutrición Hospitalaria, v. 33, n. 5, p. 1142-1148, 2016.

LIMA, J. C. R. et al. Microbiological quality, acceptability and nutritional value of cereal bars formulated with pulp and baru almond. Boletim do Centro de Pesquisa de Processamento de Alimentos, v. 28, n. 2, p. 331-343, 2010.

MARQUES, M. R. et al. Effect of cooking on the thermal behavior of the cowpea bean oil (Vigna unguiculata L. Walp). Journal of Thermal Analysis and Calorimetry, v. 120, n. 1, p. 289-296, 2015.

MÁRQUEZ-VILLACORTA, L. F.; PRETELL-VÁSQUEZ, C. C. Evaluation of quality characteristics in cereal bars with high fiber and protein content. Revista Biotecnología en el Sector Agropecuario y Agroindustrial, v. 16, n. 2, p. 67-78, 2018.

MOREIRA-ARAÚJO, R. S. R. et al. Identification and qualification of antioxidant compounds in cowpea. Revista Ciência Agronômica, v. 48, n. 5, p. 799-805, 2017.

SILVA, F. D. et al. Preparation of a quinoa cereal bar and its sensory and nutritional properties. Alimentos e Nutrição, v. 22, n. 1, p. 63-69, 2011.

SOUSA, A. M. et al. Dietetics cereal bar (umbu flavor) prepared with green banana flour. Revista de Ciencia y Tecnología, año 18, n. 25, p. 48-53, 2016. 